\title{
The Uptake and Metabolism of Glucose, Maltose and Starch by the Rumen Ciliate Epidinium ecaudatum caudatum
}

\author{
By G. S. COLEMAN AND JUDITH I. LAURIE \\ Biochemistry Department, Agricultural Research Council, \\ Institute of Animal Physiology, Babraham, Cambridge CB2 $4 A T$
}

(Received I August 1975; revised I7 February 1976)

\section{SUMMARY}

\begin{abstract}
$\left[{ }^{14} \mathrm{C}\right]$ Glucose taken up by Epidinium ecaudatum caudatum was found in the pool, in the protozoal polysaccharide and in the bacteria associated with the protozoa. The amount incorporated into the polysaccharide depended on the square of the glucose concentration. Evidence was obtained that glucose was probably taken up initially into the pool unchanged, and then rapidly converted into glucose 6phosphate and maltose which were subsequently hydrolysed to glucose. $\left.{ }^{[14} \mathrm{C}\right]-$ Maltose was taken up at 20 to $30 \%$ of the rate of $\left[{ }^{14} \mathrm{C}\right]$ glucose, with ${ }^{14} \mathrm{C}$ appearing initially in maltose and glucose 6-phosphate. ${ }^{14} \mathrm{C}$ from ${ }^{14} \mathrm{C}$-labelled soluble starch appeared in the pool as maltose, glucose 6-phosphate and glucose in that order, but incorporation into protozoal polysaccharide was poor. Hexokinase, phosphoglucomutase, $\alpha$-glucan and maltose phosphorylases, glucose 6 -phosphatase and maltase activities were found in the protozoa.
\end{abstract}

\section{INTRODUCTION}

Glucose was taken up by Entodinium caudatum (Coleman, 1969) and Ento. simplex (Coleman, 1972) either by an active process, predominant at low external glucose concentrations, or by a passive process, predominant at high concentrations. The glucose was found in the pool as free glucose, maltose and hexose phosphate and was also incorporated into protozoal polysaccharide and intracellular bacteria as a glucose polymer. There was a linear relationship, with, in some cases, a single discontinuity, between the reciprocal of the uptake of glucose into these fractions and the reciprocal of the glucose concentration. Epidinium ecaudatum caudatum (ovine) incorporated glucose into the same materials and also into protein (Coleman \& Laurie, 1974) but, in contrast to the results with Entodinium spp., the reciprocal plot for incorporation of glucose into polysaccharide against glucose concentration was curvilinear. The purpose of the present experiments was to try to explain this phenomenon. In this, they were not successful, but an examination was made of the metabolism of glucose and the mechanism of glucose uptake by the Epidinium sp. The only extensive previous studies on the carbohydrate metabolism of this protozoon have been on the carbohydrases (Bailey, I958; Bailey \& Howard, I963a, $b$; Bailey \& Gaillard, 1965).

\section{METHODS}

All experiments were made with the second and third isolates of Epi. ecaudatum caudatum (ovine), described by Coleman, Davies \& Cash (1972) and Coleman \& Laurie (1974), and a fourth isolate initiated from a single protozoon taken directly from the rumen in March 1974. All cultures behaved similarly. The preparation of protozoal suspensions, 
incubation conditions, fractionation of protozoa, analyses, radioactive techniques and chromatographic solvents were as described by Coleman (1969) and Coleman \& Laurie (1974), except that the protozoa were always suspended in salt solution D (Coleman, 1972). When the enzyme activities of the protozoal broken-cell supernatant fluid were investigated, $0.2 \%$ L-cysteine hydrochloride (neutralized) was added to the salt solution D before sonication of the protozoa.

$\alpha$-Glucan phosphorylase was assayed by measuring the rate of formation of glucose I-[32 P]phosphate plus glucose 6-[32P]phosphate from $0.33 \%(\mathrm{w} / \mathrm{v})$ soluble starch and inorganic $\left.{ }^{32} \mathrm{P}\right]$ phosphate (I to $30 \mathrm{~mm}$ ) in $0^{\circ} \mathrm{I} \mathrm{M}-\beta \beta^{\prime}$-dimethylglutarate buffer $\mathrm{pH} 7 \cdot 0$ : the glucose phosphates were separated from inorganic phosphate by chromatography in solvent $\mathrm{C}$. Glucose 6-phosphatase was assayed by measuring the rate of formation of $\left[{ }^{14} \mathrm{C}\right]$ glucose from $\left[{ }^{14} \mathrm{C}\right]$ glucose 6 -phosphate in salt solution $\mathrm{D}$. Hexokinase was assayed by measuring the rate of formation of $\left[{ }^{14} \mathrm{C}\right]$ glucose phosphates from $\left[{ }^{14} \mathrm{C}\right]$ glucose plus $17 \mathrm{mM}$-ATP in salt solution D. In both assays glucose was separated from glucose phosphates by chromatography in solvent B. Phosphoglucomutase was assayed by following the rate of formation of $\left[{ }^{14} \mathrm{C}\right]$ glucose 6-phosphate from $\left[{ }^{14} \mathrm{C}\right]$ glucose $\mathrm{I}$-phosphate in salt solution $\mathrm{D}$. The glucose phosphates were separated by chromatography in solvent C. Maltase and other sugar hydrolases were assayed as described for maltase by Coleman (I969).

Maltose phosphorylase was assayed by measuring the rate of formation of $\left[{ }^{14} \mathrm{C}\right]$ glucose or $\left[{ }^{14} \mathrm{C}\right]$ glucose $\mathrm{I}$-phosphate from $\left[{ }^{14} \mathrm{C}\right]$ maltose in salt solution $\mathrm{D}$. The ${ }^{14} \mathrm{C}$-labelled compounds were separated by chromatography in $n$-propanol/ethyl acetate $/ \mathrm{H}_{2} \mathrm{O} / \mathrm{NH}_{4} \mathrm{OH}$ (sp.gr. 0.880 ), (24:13:7:7, by vol.).

The amount of ${ }^{14} \mathrm{C}$ in the glucose moieties of $\left[{ }^{14} \mathrm{C}\right]$ maltose was determined by reduction of the maltose with sodium borohydride to $\alpha$-glucosyl sorbitol, which was separated from any unreacted maltose by electrophoresis on paper in $0.05 \mathrm{M}$-borate buffer $\mathrm{pH}$ II. The $\alpha$-glucosyl sorbitol was then eluted, hydrolysed in $\mathrm{M}-\mathrm{HCl}$ for $\mathrm{I} \mathrm{h}$ at $100{ }^{\circ} \mathrm{C}$, and the glucose and sorbitol separated by electrophoresis in $0.05 \mathrm{M}$-borate buffer $\mathrm{pH}$ II.

\section{RESULTS}

\section{Metabolism of glucose}

Effect of substrate concentration. On a reciprocal plot of the rate of incorporation of ${ }^{14} \mathrm{C}$ from $\left[\mathrm{U}^{14} \mathrm{C}\right] \mathrm{glucose}$ against substrate concentration, linear relationships were obtained for uptake into the soluble material in the cell (broken-cell supernatant fluid) and into bacteria associated with the protozoa, with maxima of 16 and $15 \mu \mathrm{mol} \mathrm{h}^{-1}$ per $10^{6}$ protozoa respectively (Fig. I). In contrast, the results for incorporation of glucose into the protozoal polysaccharide gave a curve of increasing gradient. However, when (incorporation into protozoal polysaccharide $)^{-1}$ was plotted against $(\mu \mathrm{mol} \text { glucose } / \mathrm{ml})^{-2}$, the points fell on a straight line with a maximum of $40 \mu \mathrm{mol} \mathrm{h}^{-1}$ per $10^{6}$ protozoa. This suggested that the synthesis of protozoal polysaccharide involves the reaction of two glucose molecules. If the protozoa were broken so as to liberate the associated bacteria intact before incubation with $\left[{ }^{14} \mathrm{C}\right]$ glucose, there was still a linear relationship between the rate of incorporation of ${ }^{14} \mathrm{C}$ into these bacteria and glucose concentration on a reciprocal plot; but the amount of ${ }^{14} \mathrm{C}$ incorporated was greater than in intact protozoa indicating that under this latter condition not all the bacteria were in contact with the medium.

Distribution of ${ }^{14} C$ in the broken-cell supernatant fluid. Coleman \& Laurie (1974) showed that, after incubation of protozoa with $0.7 \mathrm{~mm}-\left[{ }^{14} \mathrm{C}\right]$ glucose for $160 \mathrm{~min}, 19 \%$ of the ${ }^{14} \mathrm{C}$ in the broken-cell supernatant fluid was present in protein and $69 \%$ in the protozoal water- 


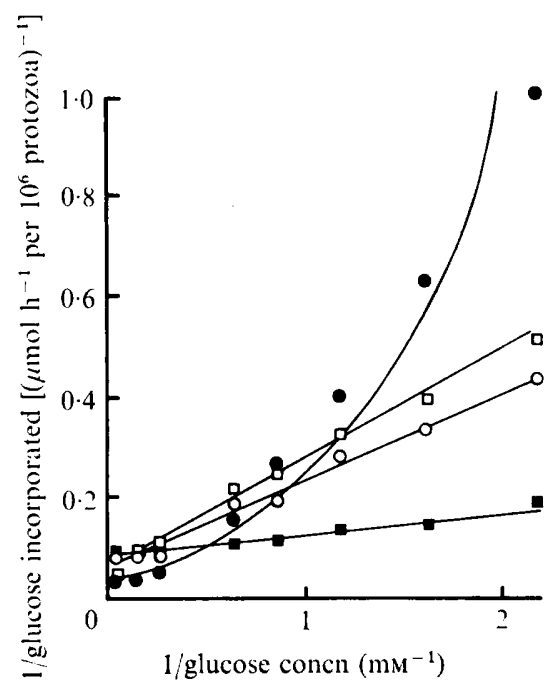

Fig. I. Effect of substrate concentration on the uptake of ${ }^{14} \mathrm{C}$ from $\left[\mathrm{U}-{ }^{14} \mathrm{C}\right] \mathrm{glucose}$ by intact and sonicated Epi. ecaudatum caudatum. After $40 \mathrm{~min}$ incubation, the sonicated protozoa were harvested and washed at $7000 \mathrm{~g}$ for $20 \mathrm{~min}(\mathbf{G})$. Intact protozoa were harvested and washed at $200 \mathrm{~g}$ for $30 \mathrm{~s}$ : they were then treated ultrasonically and separated into a supernatant fluid ( $\square$ ) and a pellet, which was subsequently fractionated by further ultrasonic treatment into a bacterial $(O)$ and a polysaccharide fraction (O).
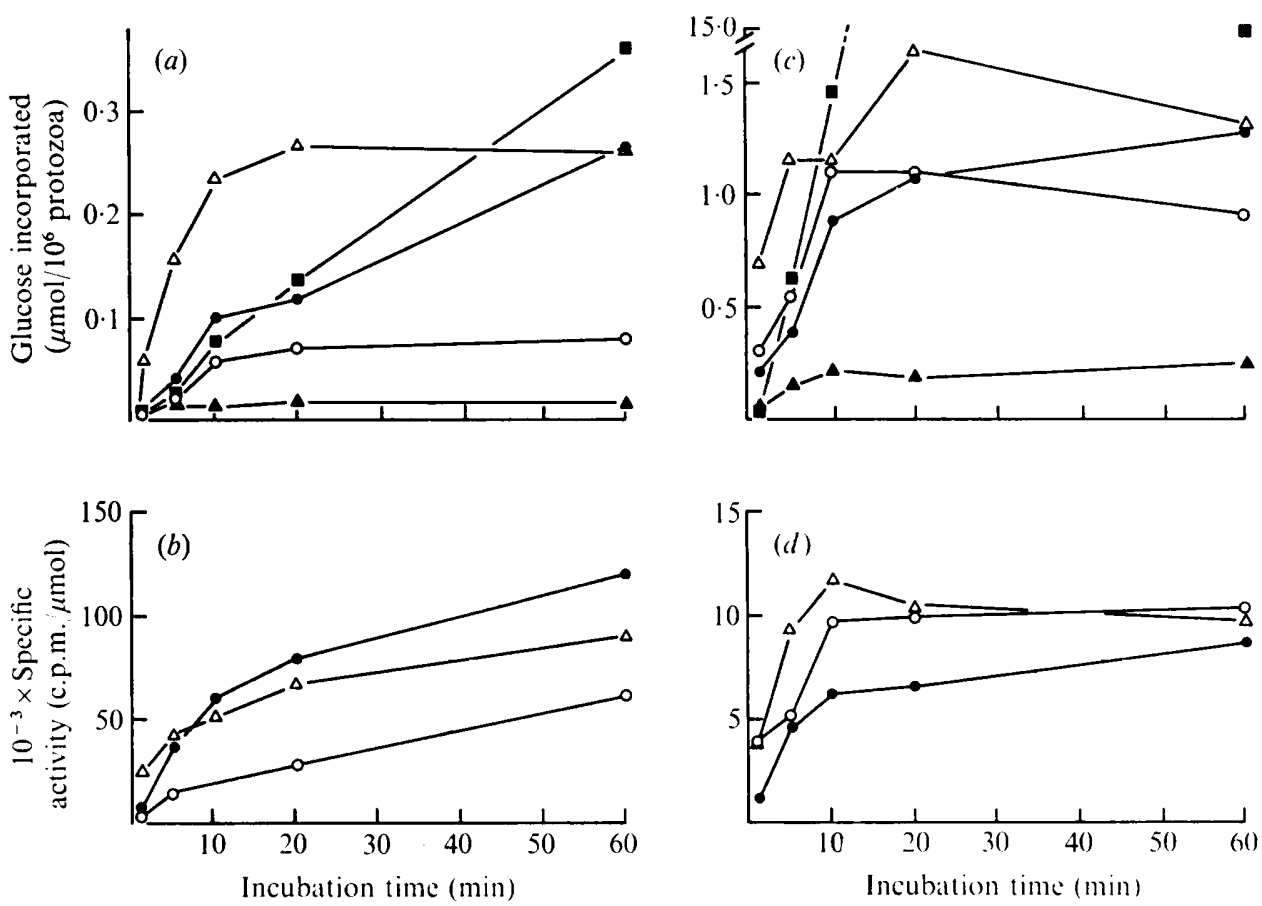

Fig. 2. Effect of incubation in the presence of $(a, b) 0.7 \mathrm{mM}-\left[\mathrm{U}-{ }^{14} \mathrm{C}\right] \mathrm{glucose}$, or $(c, d) 4^{8} \mathrm{mM}-\left[\mathrm{U}-{ }^{14} \mathrm{C}\right]-$ glucose, on the amount of ${ }^{14} \mathrm{C}$ incorporated into compounds in the pool $(a, c)$ and their specific activities $(b, d)$. $O$, Glucose;, maltose (specific activity expressed per glucose); $\mathbf{\square}$, starch; $\triangle$, glucose 6-phosphate; and $\boldsymbol{\Delta}$, glucose I-phosphate. 
soluble pool. However, after only I min incubation, over $90 \%$ of the ${ }^{14} \mathrm{C}$ was present in the pool and $\mathrm{I}$ to $2 \%$ in the protein; the proportions decreasing and increasing, respectively, with time. The principal ${ }^{14} \mathrm{C}$-labelled compounds found in the pool at all times were glucose, maltose, glucose I-phosphate and glucose 6-phosphate. The amounts $\left(\mu \mathrm{mol} / 1 \mathrm{I}^{6}\right.$ freshly harvested protozoa) of these compounds present varied from 0.70 to 3.46 for glucose, 0.58 to 2.42 for maltose and 0.50 to 3.08 for glucose 6-phosphate, with glucose to glucose 6phosphate ratios of 0.13 to 5.4 : the amount of glucose I-phosphate was too small to measure. This means that the specific activities obtained during the incorporation of $\left[{ }^{14} \mathrm{C}\right]$ glucose varied considerably between experiments.

Time course for incorporation of ${ }^{14} \mathrm{C}$ at low and high external $\left[{ }^{14} \mathrm{C}\right]$ glucose concentrations. Using a low $(0.7 \mathrm{~mm})$ external glucose concentration, ${ }^{14} \mathrm{C}$ was found first in glucose 6phosphate and then in maltose and protozoal polysaccharide (Fig. $2 a$ ). Incorporation into glucose I-phosphate was always small and reached a plateau after I to $3 \mathrm{~min}$, so it is uncertain whether or not it preceded incorporation into glucose 6-phosphate and maltose. ${ }^{14} \mathrm{C}$ usually appeared in glucose after the other compounds investigated. The rise in the specific activity of the low molecular weight compounds followed that for the total uptake (Fig. $2 b$ ). The results suggest that glucose 6-phosphate was the first product of glucose incorporation. Of the ${ }^{14} \mathrm{C}$ in the maltose, $90 \%$ was present in the reducing (glucose) moeity.

Using a high external glucose concentration, the incorporation of ${ }^{14} \mathrm{C}$ into the glucose and protozoal polysaccharide relative to incorporation into the other pool constituents (Fig. 2c) was much greater than at the low external glucose concentration. The total amounts of ${ }^{14} \mathrm{C}$ incorporated into glucose and glucose 6-phosphate in the pool, and their specific activities, were much closer at high than at low external glucose concentrations (Figs. $2 c, d$ ), showing that where appreciable amounts of glucose were passing into the protozoa, the specific activities of the compounds in the reaction chain were approximately the same as that of the initial glucose (I 4700 counts $\mathrm{min}^{-1} \mu \mathrm{mol}^{-1}$ ). After 5 min incubation, over $50 \%$ of the glucose and glucose 6-phosphate in the pool had come from the glucose in the medium.

Effect of 2-deoxyglucose on glucose metabolism. In an attempt to elucidate the reaction sequences in glucose uptake and metabolism, the effect of the inhibitor 2-deoxyglucose on the incorporation of ${ }^{14} \mathrm{C}$ from $\left[{ }^{14} \mathrm{C}\right]$ glucose was investigated. After incubation for $\mathrm{I} \mathrm{h}$ in the presence of $80 \mathrm{~mm}$-2-deoxyglucose, the incorporation of ${ }^{14} \mathrm{C}$ from a low $(0.7 \mathrm{~mm})$ external concentration of $\left[{ }^{14} \mathrm{C}\right]$ glucose into intact protozoa had decreased by $59 \%$ and that into protozoal polysaccharide and bacteria by $80 \%$ and $76 \%$ respectively. Under these conditions there was a linear relationship between incorporation of ${ }^{14} \mathrm{C}$ into protozoal polysaccharide and glucose concentration on a reciprocal plot similar to that shown in Fig. I. This suggests that, in the presence of 2-deoxyglucose, the synthesis of protozoal polysaccharide involves the reaction of single glucose molecules. However, 2-deoxyglucose either had no effect on ${ }^{14} \mathrm{C}$ incorporation into glucose in the pool, or stimulated it, and this was associated with an increase (over $100 \%$ ) in the amount of glucose present, as shown by the decrease in the specific activity. This result suggests that 2-deoxyglucose inhibited the removal of glucose from the pool. 2-Deoxyglucose decreased the incorporation of ${ }^{14} \mathrm{C}$ into glucose 6-phosphate by $72 \%$, while the amount of glucose 6-phosphate in the pool decreased by $45 \%$ suggesting that formation of this compound was inhibited, and its removal was either unchanged or stimulated.

Effect of temperature on glucose metabolism. As the rate of an enzyme reaction is more sensitive to change in temperature than is the rate of a physical process such as diffusion (Coleman, 1969), an investigation was made of the effect of lowering the incubation tem- 
perature on the distribution of ${ }^{14} \mathrm{C}$ from $\left[{ }^{14} \mathrm{C}\right]$ glucose between the various glucose derivatives. On incubation of $0.7 \mathrm{~mm}-\left[{ }^{14} \mathrm{C}\right]$ glucose with Epi. ecaudatum caudatum for $5 \mathrm{~min}$, the amounts of ${ }^{14} \mathrm{C}$ incorporated into the pool and into protozoal polysaccharide were 0.74 and 0.52 respectively at $30{ }^{\circ} \mathrm{C}$, and 0.46 and 0.09 at $20^{\circ} \mathrm{C}$, relative to those at $39{ }^{\circ} \mathrm{C}$ (taken as I). Of the labelled pool constituents, the amount of ${ }^{14} \mathrm{C}$ in glucose 6-phosphate decreased more rapidly with fall in temperature than that of the total pool, whereas that of glucose remained constant or, in some experiments, doubled. As the total amount of glucose in the pool decreased more rapidly at $20^{\circ} \mathrm{C}$ or $30^{\circ} \mathrm{C}$ than at $39{ }^{\circ} \mathrm{C}$, the specific activity of the pool glucose was always higher ( 8 to $22 \%$ ) at $20{ }^{\circ} \mathrm{C}$ than at $39^{\circ} \mathrm{C}$. The amount of glucose 6-phosphate in the pool was usually lower (up to $20 \%$ ) at $20{ }^{\circ} \mathrm{C}$ than at $39{ }^{\circ} \mathrm{C}$. These results suggest that glucose was taken up unchanged and then phosphorylated, and that the uptake reaction was less sensitive to fall in temperature than the phosphorylation step and so could be a diffusion process.

At a high external glucose concentration $(40 \mathrm{~mm})$, the total amount of glucose, maltose and glucose 6-phosphate in the pool was higher at $20^{\circ} \mathrm{C}$ than at $39^{\circ} \mathrm{C}$ after 5 min incubation, but only with glucose was more (over $90 \%$ ) than $20 \%$ of the pool material derived from external glucose. Over this period, the amount of $\left[{ }^{14} \mathrm{C}\right]$ glucose in the pool was $55 \%$ higher at $20{ }^{\circ} \mathrm{C}$ than at $39{ }^{\circ} \mathrm{C}$ whereas the amounts of $\left[{ }^{14} \mathrm{C}\right]$ maltose and $\left[{ }^{14} \mathrm{C}\right]$ glucose $6-$ phosphate were 25 to $35 \%$ lower. These differences between glucose and the other pool constituents suggest that, at high glucose concentrations, a decrease in the temperature did not hinder and may even have facilitated the entry of glucose into the protozoon, and that this took place faster than the rate at which the glucose was metabolized. Again, the results suggest that glucose might enter the organism by a diffusion process.

Iodoacetate $(0.8 \mathrm{~mm})$, which is an inhibitor of glycolysis and hence important energyproducing reactions, inhibited the uptake of ${ }^{14} \mathrm{C}$ from low concentrations of glucose into intact protozoa by 25 to $30 \%$ during a 10 min incubation. Incorporation into protozoal polysaccharide was inhibited by $60 \%$ and into pool glucose 6-phosphate by $25 \%$, whereas incorporation into pool glucose was stimulated by $200 \%$, again suggesting that glucose was taken up into the pool by an energy-independent process but was then metabolized by energy-dependent reactions.

\section{Metabolism of maltose}

In contrast to the results obtained with Ento. caudatum (Coleman, I969), where maltose was taken up four times as fast as glucose, Epi. ecaudatum caudatum took up ${ }^{14} \mathrm{C}$ from maltose at only 20 to $30 \%$ of the rate at which it took up ${ }^{14} \mathrm{C}$ from glucose at the same molarity. A reciprocal plot of incorporation of carbon into intact protozoa or the broken-cell pellet against maltose concentration gave two straight lines with a discontinuity at $\mathrm{I} \cdot 5 \mathrm{~mm}$, rather than a curve, as was found with glucose. The proportion of the ${ }^{14} \mathrm{C}$ incorporated that was found in protozoal polysaccharide did not increase with increasing substrate concentration as was observed with glucose, suggesting that the two sugars were taken up by different mechanisms.

${ }^{14} \mathrm{C}$ from $\left[{ }^{14} \mathrm{C}\right]$ maltose appeared initially in maltose and glucose 6-phosphate in the pool. There was also appreciable incorporation into glucose although, both in terms of total ${ }^{14} \mathrm{C}$ and specific activity, incorporation was always less rapid than into the first two compounds. Uptake into glucose I-phosphate was too small to measure. In the presence of $80 \mathrm{~mm}-2$-deoxyglucose, the incorporation into all fractions was decreased by $65 \%$. This suggests that 2-deoxyglucose inhibits the uptake of maltose; but, once taken up, the maltose is metabolized in the same way as in the absence of the inhibitor. 

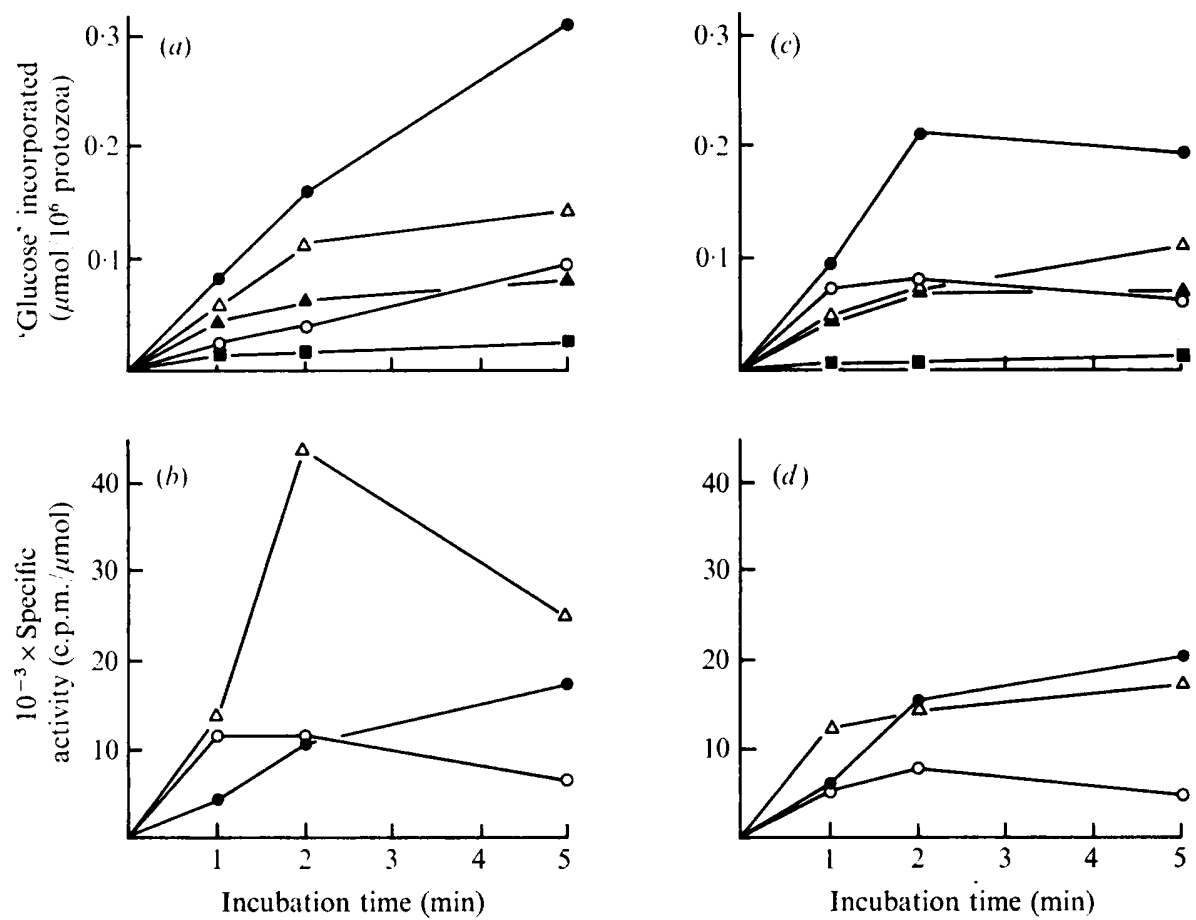

Fig. 3. Effect of incubation in the presence of $(a, b) 0.36 \mathrm{mg}$ soluble $\left[\mathrm{U}-{ }^{14} \mathrm{C}\right] \mathrm{starch} / \mathrm{ml}$, or $(c, d)$ $0.36 \mathrm{mg}$ soluble [U-14 $\mathrm{C}$ ]starch $/ \mathrm{ml}$ plus $80 \mathrm{~mm}$-2-deoxyglucose, on the amount of ${ }^{14} \mathrm{C}$ incorporated into compounds in the pool $(a, c)$ and their specific activities $(b, d)$. Symbols as in Fig. 2.

\section{Metabolism of starch}

On incubation of the protozoa with soluble $\left[{ }^{14} \mathrm{C}\right]$ starch, there was a rapid uptake of ${ }^{14} \mathrm{C}$ that appeared sequentially in! maltose, glucose 6-phosphate and glucose (Fig. 3). Incorporation into protozoal polysaccharide was slow. The specific activity of the glucose 6-phosphate was greater than that of the free sugars (Figs. $3 a, b$ ) although the actual values depended on the size of the pools present initially. Glucose I-phosphate was more heavily labelled than when the protozoa were incubated in the presence of $\left[{ }^{14} \mathrm{C}\right]$ glucose. These results suggest that at least some of the glucose 6-phosphate was formed from starch by a mechanism that did not involve hydrolysis to maltose and glucose followed by the phosphorylation of the latter; and that glucose I-phosphate may be an important intermediate in the formation of glucose 6-phosphate.

In the presence of $80 \mathrm{~mm}$-2-deoxyglucose (Figs. $3 c, d$ ), uptake of ${ }^{14} \mathrm{C}$ by intact protozoa decreased by $32 \%$, and incorporation into protozoal polysaccharide decreased by $52 \%$. However, the proportion of the ${ }^{14} \mathrm{C}$ incorporated in the presence of inhibitor that was found in free glucose increased from 3 to $14 \%$, that in free maltose from I I to $18 \%$, and that in 'glucose 6-phosphate from 5 to $9 \%$, and the ratio of the amount of ${ }^{14} \mathrm{C}$ in glucose to that in glucose 6-phosphate increased from 0.67 to $\mathrm{I} \cdot 55$. These results show that the rate of metabolism of pool constituents derived from the starch and, in particular, the rate of phosphorylation of pool glucose were probably both decreased by 2-deoxyglucose. 


\section{Table I. Kinetic constants of some enzymes of Epi. ecaudatum caudatum}

\begin{tabular}{|c|c|c|c|c|}
\hline $\begin{array}{l}\text { Protozoal } \\
\text { fraction* }\end{array}$ & Enzyme & Substrate & $\begin{array}{l}\text { Maximum } \\
\text { velocity } \\
\left(\mu \mathrm{mol} \mathrm{min}^{-1} \text { per }\right. \\
\left.10^{6} \text { protozoa }\right)\end{array}$ & $\begin{array}{c}K_{\mathrm{m}} \\
(\mathrm{mM})\end{array}$ \\
\hline BCS & Hexokinase & Glucose, 17 mM-ATP & $0.22 \dagger$ & $I \cdot 05$ \\
\hline $\mathrm{BCS}$ & Phosphoglucomutase & Glucose I-phosphate & 0.13 & 0.88 \\
\hline BCS & Maltase & Maltose & 0.45 & 13 \\
\hline BCS & Cellobiase & Cellobiose & $1 \cdot 3$ & $I \cdot 5$ \\
\hline BCS & Glucose 6-phosphatase & Glucose 6-phosphate & $2 \cdot 45$ & $2 \cdot 5$ \\
\hline BCP & $\alpha$-Glucan phosphorylase & $\begin{array}{l}0.33 \% \text { Soluble starch, } \\
\text { phosphate }\end{array}$ & $0.85 \div$ & $6 \cdot 7$ \\
\hline \multirow[t]{2}{*}{ BCP } & Maltose phosphorylase & $\begin{array}{l}\text { Maltose, } 73 \mathrm{mM}- \\
\text { phosphate }\end{array}$ & $2 \cdot 3 \dagger \S$ & $15 \cdot 5$ \\
\hline & \multicolumn{4}{|c|}{$\begin{array}{l}\text { * BCS, Broken-cell supernatant fluid; BCP, broken-cell pellet. } \\
\text { † Measured at infinite sugar concentration. } \\
\ddagger \text { Phosphate esterified at infinite phosphate concentration. } \\
\S \text { Formation of glucose I-phosphate. }\end{array}$} \\
\hline
\end{tabular}

\section{Enzyme activities present in broken-cell supernatant fluid}

The kinetic constants of the enzymes are given in Table I. In an attempt to explain the stimulatory effect of high concentrations of glucose on polysaccharide synthesis and the action of 2-deoxyglucose on the level of compounds in the pool, we investigated the effect of potentially inhibitory or stimulatory compounds on the action of hexokinase and phosphoglucomutase.

Hexokinase (ATP:D-hexose 6-phosphotransferase; EC. 2.7.I.I). Phosphoenolpyruvate (PEP) was completely inactive with this enzyme. In the first minute of incubation of intact protozoa with $80 \mathrm{~mm}$-glucose, 0.14 to $0.45 \mu$ mol glucose 6 -phosphate per $10^{6}$ protozoa were formed; the enzyme was almost sufficiently active (Table $\mathrm{I}$ ) to account for a conversion of this magnitude. The action of inhibitors and of $\left[{ }^{12} \mathrm{C}\right]$ glucose was investigated in the presence of $0.17 \mathrm{~mm}-\left[{ }^{14} \mathrm{C}\right] \mathrm{glucose}$ in an experiment of $30 \mathrm{~min}$ duration. The rates of conversion, relative to the rate in the absence of added material $(=100)$, were: 80 with 7 mM-2-deoxyglucose; 72 with 7 mM-2-deoxyglucose 6-phosphate; 87 with 7 mM-glucose 6-phosphate; I 3 with 100 mM-glucose; and 29 with 7 mm-glucose.

Phosphoglucomutase ( $\alpha$-D-glucose 1,6-bisphosphate: $\alpha$-D-glucose I-phosphate phosphotransferase; EC. 2.7.5.I). In the presence of $0.005 \mathrm{mM}$-glucose $\mathrm{I}$-phosphate, the rate of formation of glucose 6-phosphate was not affected by $2.5 \mathrm{mM}$-glucose or 2-deoxyglucose, but it was decreased by $40 \%$ in the presence of $2.5 \mathrm{~mm}$-2-deoxyglucose 6 -phosphate. The action of inhibitors (at $15 \mathrm{~mm}$ ) on the reverse reaction was investigated in the presence of $0.09 \mathrm{~mm}$-glucose 6-phosphate. The rates of conversion, relative to the rate in the absence of added compounds $(=100)$ were: IOI with glucose; 9I with 2-deoxyglucose; $5 \mathrm{I}$ with glucose 6-phosphate; 49 with glucose I-phosphate; and 66 with 2-deoxyglucose 6-phosphate.

Maltase ( $\alpha$-D-glucoside glucohydrolase; EC. 3.2 . I . 20). ${ }^{14} \mathrm{C}$ from $\left[{ }^{14} \mathrm{C}\right]$ glucose was rapidly incorporated into maltose in the pool of intact protozoa. Since this could have occurred by the reversal of the hydrolytic action of maltase, the activity of this enzyme was investigated. $\left[{ }^{14} \mathrm{C}\right]$ Glucose was the only product from $6.7 \mathrm{~mm}-\left[{ }^{14} \mathrm{C}\right]$ maltose and the reaction was progressively inhibited by increasing concentrations of $\left[{ }^{12} \mathrm{C}\right]$ glucose $(50 \%$ decrease in rate 


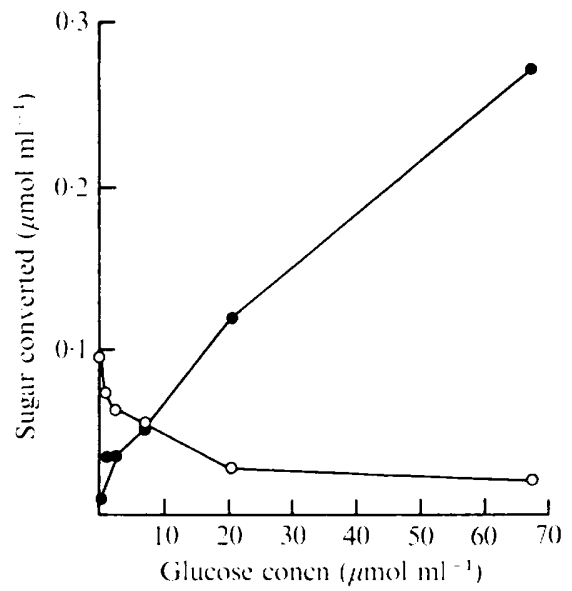

Fig. 4. Effect of glucose concentration on the transfer in $60 \mathrm{~min}$ of ${ }^{14} \mathrm{C}$ from $\left[\mathrm{U}-{ }^{14} \mathrm{C}\right] \mathrm{glucose}$ to $6.7 \mathrm{~mm}$ maltose $(\mathrm{O})$, and from $6.7 \mathrm{mM}\left[\mathrm{U}^{14} \mathrm{C}\right]$ maltose to glucose $(\mathrm{O})$, in the presence of brokencell supernatant fluid from $10^{5}$ protozoa.

in presence of $8 \mathrm{~mm}$-glucose) as shown in Fig. 4. By reversing the labelling of the two sugars, it was shown that glucose carbon was incorporated into maltose at a constant rate for $60 \mathrm{~min}$. When incubation took place with $6.7 \mathrm{mM}$-maltose and $67 \mathrm{mM}-\left[{ }^{14} \mathrm{C}\right]$ glucose, the maltose contained $0.27 \mu \mathrm{mol}$ glucose carbon $/ \mathrm{ml}$ after $60 \mathrm{~min} ; 65 \%$ of the glucose carbon was in the reducing glucose moiety. Thus, although glucose carbon was incorporated into maltose, the reaction did not occur fast enough to explain the reaction in vivo where the two sugars were present in approximately equimolar amounts.

Glucose 6-phosphatase (D-glucose 6-phosphate phosphohydrolase; EC. 3.1.3.9). The action of possible inhibitors was determined in the presence of $0.01 \mathrm{~mm}$-glucose 6-phosphate. The rates of reaction, relative to the rate in the absence of added compounds $(=100)$ were: I00 with I $5 \mathrm{~mm}$-glucose, I00 with I5 mM-2-deoxyglucose, 82 with I.5 mM- and 45 with 7.5 mm-2-deoxyglucose 6-phosphate; and 37 with 7.5 mm-glucose 6 -phosphate.

\section{Enzyme activities present in broken-cell pellet}

The following activities, not found in the broken-cell supernatant fluid, were all measured in the washed pellet obtained after breaking the protozoa and centrifuging at $7000 \mathrm{~g}$.

$\alpha$-Glucan phosphorylase (I,4- $\alpha$-D-glucan:orthophosphate $\alpha$-glycosyltransferase; EC. 2.4.I.I). Although this enzyme was only found in the pellet fraction, an experiment to determine its likely importance to the protozoa was made with a crude broken-cell preparation (centrifuged at $200 \mathrm{~g}$ to remove large particles). This was incubated for $30 \mathrm{~min}$ with soluble $\left[{ }^{14} \mathrm{C}\right]$ starch in the presence or absence of added inorganic phosphate $(5 \mathrm{~mm})$ or ATP $(0.67 \mathrm{~mm})$. In the absence of either compound, $4.8 \%$ of the ${ }^{14} \mathrm{C}$ was found in glucose phosphates, $37 \%$ in maltose and $18 \%$ in glucose. In the presence of phosphate or ATP, the corresponding results were, respectively: $7.0 \%, 19.4 \%$ in glucose phosphates $; 38.5 \%$, $35.2 \%$ in maltose; and $23.2 \%$ and $10.0 \%$ in glucose. Thus most of the starch was probably metabolized to glucose phosphate by phosphorylation after hydrolysis rather than by direct phosphorolysis.

Maltose phosphorylase (maltose: orthophosphate $\alpha$-glucosyltransferase; EC. 2.4 . I .8). To measure the rate of exchange of carbon between maltose, glucose and glucose I-phosphate, I $\mathrm{mm}$ amounts of each were uniformly labelled, in turn, with ${ }^{14} \mathrm{C}$ and incubated with the enzyme preparation. After Io min, approximately one molecule of glucose or glucose 


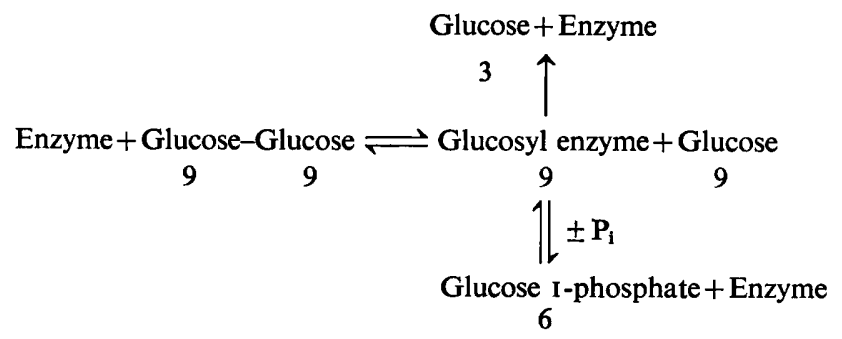

Fig. 5. Probable reaction mechanism for maltose phosphorylase of Epidinium ecaudatum caudatum. The figures indicate the percentage of the $\left[{ }^{14} \mathrm{C}\right]$ maltose present that was metabolized. Maltose is represented as Glucose-Glucose.

I-phosphate had been incorporated into maltose for each two molecules of maltose broken down. These results are consistent with the reaction scheme in Fig. 5, which shows another possible mechanism for the incorporation of ${ }^{14} \mathrm{C}$ from $\left[{ }^{14} \mathrm{C}\right]$ glucose into maltose.

UDPG pyrophosphorylase (UTP: $\alpha$-D-glucose $\mathrm{I}$-phosphate uridylyltransferase; EC. 2.7.7.9). Attempts to demonstrate the presence of this enzyme by incubation of protozoal extracts with $\left[{ }^{14} \mathrm{C}\right]$ glucose I-phosphate and UTP or ATP were unsuccessful.

\section{DISCUSSION}

Although at low glucose concentrations, glucose 6-phosphate was the first product derived from the uptake of glucose, and 2-deoxyglucose inhibited the uptake of glucose by the protozoa, 2-deoxyglucose did not greatly inhibit the formation of glucose 6-phosphate from glucose and ATP by broken-cell supernatant fluid. It is therefore suggested that glucose was taken up unchanged, in a reaction inhibited by 2-deoxyglucose, and then rapidly phosphorylated to glucose 6-phosphate by an enzyme that was not inhibited by 2-deoxyglucose. On incubation of the protozoa with $\left[{ }^{14} \mathrm{C}\right]$ glucose, ${ }^{14} \mathrm{C}$ appeared in pool glucose after it appeared in glucose 6-phosphate, so it is probable that this compound was hydrolysed to glucose. In the presence of 2-deoxyglucose, the amount of glucose in the pool increased. As this was not the result of increased uptake, it could have been caused by an inhibition of the phosphorylation of glucose in the pool, although it is also possible that 2-deoxyglucose inhibited the removal of glucose from the pool by another reaction.

To explain these observations, it is postulated that there are two pools and two hexokinases in this protozoon. Glucose passes into the first pool by an energy-independent process; this uptake is inhibited by 2-deoxyglucose. It is then transferred from this pool to the second pool and, at the same time, phosphorylated by the action of the first hexokinase to glucose 6-phosphate, which is subsequently dephosphorylated to glucose; the initial phosphorylation and transfer would be energy dependent. The second pool contains most of the free sugars and their derivatives: these compounds are released into this pool after degradation of polysaccharide or removed from it for polysaccharide synthesis. The second hexokinase and the phosphoglucomutase are also in this pool. At $39^{\circ} \mathrm{C}$, the first pool must be very small as $\left[{ }^{14} \mathrm{C}\right]$ glucose 6-phosphate is formed very quickly from external $\left[{ }^{14} \mathrm{C}\right]$ glucose (Fig. 2a). However, in the presence of iodoacetate or at low temperature, it could increase in size, with the increased amount of $\left[{ }^{14} \mathrm{C}\right]$ glucose in the protozoa under these conditions being in this first rather than the second pool. As PEP was completely inactive in the phosphorylation of glucose, it is unlikely that a system similar to the bacterial phosphotransferase uptake mechanism (Roseman, 1969) was active in this protozoon. 
In the presence of 2-deoxyglucose, the amount of ${ }^{14} \mathrm{C}$ incorporated into protozoal polysaccharide decreased to a greater extent than did the specific activity of the glucose 6phosphate, suggesting the existence of another inhibitory site. As 2-deoxyglucose is phosphorylated to 2-deoxyglucose 6-phosphate by protozoal extracts and as this compound inhibits phosphoglucomutase, it is likely that the enzyme is the site of inhibition, assuming that glucose I-phosphate is an intermediate as in other protozoa (Manners, I974).

On incubation of protozoa with high specific activity $\left[{ }^{14} \mathrm{C}\right]$ glucose, maltose is labelled more rapidly and to a higher specific activity than glucose; thus, maltose cannot become labelled by degradation of polysaccharide synthesized from $\left[{ }^{14} \mathrm{C}\right] g l u c o s e$, nor by exchange of one glucose moiety with the bulk free glucose in the pool, i.e. the second pool of the above hypothesis. Initially the specific activity of maltose was only a little less than that of glucose 6-phosphate, so it is possible that maltose was labelled after conversion of glucose 6phosphate to glucose I-phosphate which then exchanged glucose units with maltose by the action of maltose phosphorylase. However, the finding that the reducing glucose in maltose was most heavily labelled under these conditions does not support this view (Fig. 5) and suggests that high specific activity glucose from the medium must exchange with glucose in maltose before mixing with the bulk of the free glucose in the pool, i.e. it must exchange in the first pool.

The time course for the appearance of ${ }^{14} \mathrm{C}$ from $\left[{ }^{14} \mathrm{C}\right]$ starch in sugars and sugar derivatives shows that, compared with experiments with $\left[{ }^{14} \mathrm{C}\right]$ glucose, maltose and glucose $\mathrm{I}$-phosphate were more heavily labelled. As maltose phosphorylase is more active than starch phosphorylase in protozoal extracts, starch is possibly first hydrolysed to maltose which then undergoes hydrolysis to glucose or phosphorolysis to glucose and glucose I-phosphate. Both these compounds would then be converted to glucose 6-phosphate. Glucose 6-phosphate in the pool initially has a much higher specific activity than maltose (Fig. 3). This condition could only arise if the starch phosphorylase was much more active in intact protozoa than in vitro, or if there were, as described above, two compartments in the protozoon containing compounds of different specific activity. In the presence of 2-deoxyglucose, the amount of ${ }^{14} \mathrm{C}$ in glucose relative to that in the other compounds, and the amount in glucose I-phosphate relative to that in glucose 6-phosphate, both increased, again suggesting that phosphorylation of glucose and the phosphoglucomutase reactions were inhibited.

The reason why polysaccharide synthesis from glucose depends on the square of the substrate concentration in this Epidinium sp. but directly on the substrate concentration in Entodinium spp. (Coleman, 1969, 1972) is not known. The linear relationship with finite maximum velocity between uptake of glucose into the pool of the Epidinium sp. and glucose concentration on a reciprocal plot suggests that the overall uptake of glucose into the main or second pool is an active process although, as shown above, the first stage may be energy independent. In Entodinium spp., glucose is taken up into the pool by an active process, predominant at low concentrations, and by a passive one, predominant at high concentrations (Coleman, I969, 1972). Glucose is taken up by the Epidinium sp. over Ioo times more rapidly than by Entodinium spp. but it is not known if these differences are of any significance. In the Epidinium sp., the ratio of glucose I-phosphate to glucose 6-phosphate is higher at high glucose concentrations than at low concentrations, but there is no other evidence to suggest why a larger proportion of the assimilated glucose is converted into polysaccharide under this condition or why maltose is not metabolized in the same way. None of the reactions studied was stimulated at high concentrations of glucose or glucose 6-phosphate. 
We wish to thank the members of the Sub-Department of Chemical Microbiology, Biochemistry Department, University of Cambridge, for their helpful advice and criticism, and Miss J. E. Bailey for valuable technical assistance.

\section{REFERENCES}

BAILEY, R. W. (1958). Bloat in cattle. Io. The carbohydrases of the cattle rumen ciliate Epidinium ecaudatum Crawley isolated from cows fed on red clover (Trifolium pratense L). New Zealand Journal of Agricultural Research I, 825-833.

Bailey, R. W. \& GaIllaRD, S. E. D. (1965). Carbohydrases of the rumen ciliate Epidinium ecaudatum (Crawley). Hydrolysis of plant hemicellulose fractions and $\beta$-linked glucose polymers. Biochemical Journal 95, 758-766.

BAILEY, R. W. \& HowARD, B. H. (1963a). Carbohydrases of the rumen ciliate Epidinium ecaudatum (Crawley). 2. $\alpha$-Galactosidase and isomaltase. Biochemical Journal 87, I46-I II.

Bailey, R. W. \& Howard, B. H. (1963b). The biochemistry of rumen protozoa. 6. The maltases of Dasytricha ruminantium, Epidinium ecaudatum (Crawley) and Entodinium caudatum. Biochemical Journal 86, 446-452.

Coleman, G. S. (1969). The metabolism of starch, maltose, glucose and some other sugars by the rumen ciliate Entodinium caudatum. Journal of General Microbiology 57, 303-332.

Coleman, G. S. (1972). The metabolism of starch, glucose, amino acids, purines, pyrimidines and bacteria by the rumen ciliate Entodinium simplex. Journal of General Microbiology 71, I17-I 3I.

Coleman, G. S., Davies, J. I. \& CASH, M. A. (1972). The cultivation of the rumen ciliates Epidinium ecaudatum caudatum and Polyplastron multivesiculatum in vitro. Journal of General Microbiology 73, 509-521.

Coleman, G. S \& LAURIE, J. I. (I974). The metabolism of starch, glucose, amino acids, purines, pyrimidines and bacteria by three Epidinium spp. isolated from the rumen. Journal of General Microbiology $85,244-256$.

MANNERs, D. J. (1974). The structure and metabolism of starch. In Essays in Biochemistry, vol. 10, pp. 37-7I. Edited by P. N. Campbell and F. Dickens. London: Academic.

Roseman, S. (1969). The transport of carbohydrates by a bacterial phosphotransferase system. Journal of General Physiology 54, I38s-180s. 